\title{
Filarioid infections in wild carnivores: a multispecies survey in Romania
}

\author{
Angela Monica Ionică ${ }^{*}$, loana Adriana Matei ${ }^{1}$, Gianluca D'Amico', Jana Ababii', \\ Aikaterini Alexandra Daskalaki ${ }^{1}$, Attila D. Sándor ${ }^{1}$, Dorin Valter Enache², Călin Mircea Gherman ${ }^{1}$ \\ and Andrei Daniel Mihalca ${ }^{1}$
}

\begin{abstract}
Background: Filarioids are vector-borne parasitic nematodes of vertebrates. In Europe, eight species of filarioids, including zoonotic species, have been reported mainly in domestic dogs, and occasionally in wild carnivores. In Romania, infections with Dirofilaria spp. and Acanthocheilonema reconditum are endemic in domestic dogs. Despite the abundant populations of wild carnivores in the country, their role in the epidemiology of filarioid parasites remains largely unknown. The aim of the present study was to assess the host range, prevalence and distribution of filarioid infections in wild carnivores present in Romania.

Methods: Between May 2014 and February 2016, 432 spleen samples originating from 14 species of wild carnivores have been tested for the presence of DNA of three species of filarioids (D. immitis, D. repens and A. reconditum).

Results: Overall 14 samples (3.24\%) were molecularly positive. The most prevalent species was D. immitis (1.62\%), accounting for $50 \%(n=7)$ of the positive animals. The prevalence of $D$. repens was $1.39 \%$, while that of $A$. reconditum was $0.23 \%$. No co-infections were detected. Dirofilaria immitis DNA was detected in five golden jackals, Canis aureus (7. $58 \%)$, one red fox, Vulpes vulpes (0.33\%), and one wildcat, Felis silvestris (10\%). The presence of D. repens DNA was detected in two red foxes (0.66\%), two golden jackals (3.03\%), one grey wolf (7.14\%), and one least weasel, Mustela nivalis (33.33\%). Acanthocheilonema reconditum DNA was found only in one red fox (0.33\%).
\end{abstract}

Conclusion: The present study provides molecular evidence of filarial infections in wild carnivore species in Romania, suggesting their potential epidemiological role and reports a new host species for D. repens.

Keywords: Wild carnivores, Dirofilaria spp., Acanthocheilonema reconditum, Infection, Romania

\section{Background}

Filarioids (Spirurida, Onchocercidae) are vector-borne parasitic nematodes that reside in various tissues of vertebrates [1]. In Europe, eight species of filarioids of four genera (Dirofilaria: 2 species; Acanthocheilonema: 2 species; Cercopithifilaria: 3 species; and Onchocerca lupi) have been reported in domestic dogs. Among these, most of the research has been focused on the zoonotic species, namely $D$. immitis, which causes a severe and life-threatening cardio-pulmonary disease in dogs [2], D. repens, which resides in the subcutaneous tissues

\footnotetext{
* Correspondence: ionica.angela@usamvcluj.ro

${ }^{1}$ Department of Parasitology and Parasitic Diseases, Faculty ofveterinary Medicine, University of Agricultural Sciences and Veterinary Medicine Cluj-Napoca, Calea Mănăștur 3-5, 400372 Cluj-Napoca, Romania Full list of author information is available at the end of the article
}

of the canine host and is associated with a variety of dermatological conditions $[3,4]$ and, more recently, $O$. lupi, which is localized in the connective tissue of the sclera or in the retrobulbar regions of the eye of dogs [5]. Acanthocheilonema spp. and Cercopithifilaria spp. have a less known ecology, as they seem to be nonpathogenic, and have a minimal clinical importance [6]. Globally, there are several records of free-roaming wild carnivores being naturally infected with filarioid helminths that typically parasitize domestic dogs [7-32]. However, in Europe, only a few extensive studies assessing the prevalence, distribution and mainly patency (i.e. presence of circulating microfilariae) of filarial infections in wild carnivores have been published [7-18, 21].

Dirofilaria spp. and A. reconditum are distributed in dog populations throughout the country [33], while 
other species (C. bainae, O. lupi) have been reported only locally $[34,35]$. Romania is mostly a rural country, having an extended wildlife-domestic animal interface, which may facilitate the spreading of canine parasites to wild carnivores, which in turn may act as natural reservoirs. The country is characterized by a high diversity of habitats and biodiversity, having a rich wild carnivore fauna comprising 18 species belonging to 5 families: Mustelidae (10 species), Canidae (4 species), Felidae (2 species), Ursidae (1 species) and Phocidae (1 species) [36]. However, despite this large diversity and abundance of wild carnivores present in the country, their role in the epidemiology of filarioid parasites remains unknown. The aim of the present study was to assess the prevalence and distribution of filarioid infections in wild carnivores present in Romania.

\section{Methods}

Between May 2014 and February 2016, a total of 432 spleen samples originating from 14 species of wild carnivores have been tested (Table 1). The animals were legally hunted, road-killed, or found dead due to natural causes at various locations. For each animal, species, sex, estimated age (juvenile or adult, according to dentition) and collection site were recorded. Collection of samples took place either directly on the field (performed by hunters), or during necropsy. All necropsies were performed at the Department of Parasitology and Parasitic Diseases within the University of Agricultural Sciences and Veterinary Medicine of Cluj-Napoca (Romania). When available, the heart and pulmonary arteries were dissected in order to assess the presence of adults of $D$. immitis. Samples were labelled and stored at $-20{ }^{\circ} \mathrm{C}$ until further processing.

Genomic DNA was extracted individually from up to $20 \mathrm{mg}$ of splenic tissue using a commercial kit (Isolate II Genomic DNA Kit, Bioline, London, UK) according to the manufacturer's instructions. The detection of filarioid DNA was performed by means of multiplex PCR discriminating three species of filarioids commonly present in Europe (D. immitis, D. repens and A. reconditum), using primers and protocols available in literature [37]. PCR products were visualised under UV light after electrophoresis in a $2 \%$ agarose gel stained with Red$\mathrm{Safe}^{\mathrm{Tx}}$ 20,000× Nucleic Acid Staining Solution (Chembio, St Albans, UK). The size of the attained bands was assessed by comparison to a molecular marker (O'GeneRuler $^{\text {Tw }} 100$ bp DNA Ladder, Thermo Fisher Scientific Inc., Waltham, MA, USA).

The frequency and prevalence of infection and their 95\% confidence intervals (95\% CI) were established using EpiInfo ${ }^{\text {tw }} 7$ software (CDC, USA).

\section{Results}

Overall, 432 spleen samples were tested for the presence of DNA of three filarioid species. A total of 14 samples were positive (3.24\%; 95\% CI: $1.94-5.37 \%$ ). Dirofilaria immitis DNA was detected in the spleen of five golden jackals, Canis aureus, one red fox, Vulpes vulpes, and one wildcat, Felis silvestris (Table 1). Additionally, heartworms were also present in the right ventricle or pulmonary arteries of one Eurasian

Table 1 Animal species examined in the present study and molecular screening results

\begin{tabular}{|c|c|c|c|c|c|c|c|c|}
\hline \multirow[t]{2}{*}{ Family } & \multirow[t]{2}{*}{ Species } & \multirow[t]{2}{*}{$n$} & \multicolumn{2}{|c|}{ D. immitis } & \multicolumn{2}{|l|}{ D. repens } & \multicolumn{2}{|c|}{ A. reconditum } \\
\hline & & & $n(\%)$ & $95 \% \mathrm{Cl}$ & $n(\%)$ & $95 \% \mathrm{Cl}$ & $n(\%)$ & $95 \% \mathrm{Cl}$ \\
\hline \multirow[t]{3}{*}{ Canidae } & Vulpes vulpes & 305 & $1(0.33)$ & $0.06-1.83$ & $2(0.66)$ & $0.18-2.36$ & $1(0.33)$ & $0.06-1.83$ \\
\hline & Canis aureus & 66 & $5(7.58)$ & $2.51-16.80$ & $2(3.03)$ & $0.37-10.52$ & 0 & - \\
\hline & Canis lupus & 14 & 0 & - & $1(7.14)$ & $0.18-33.87$ & 0 & - \\
\hline \multirow[t]{2}{*}{ Felidae } & Felis silvestris & 10 & $1(10)$ & $0.25-44.50$ & 0 & - & 0 & - \\
\hline & Lynx lynx & 4 & 0 & - & 0 & - & 0 & - \\
\hline \multirow[t]{8}{*}{ Mustelidae } & Lutra lutra & 7 & 0 & - & 0 & - & 0 & - \\
\hline & Meles meles & 5 & 0 & - & 0 & - & 0 & - \\
\hline & Mustela lutreola & 4 & 0 & - & 0 & - & 0 & - \\
\hline & Mustela putorius & 3 & 0 & - & 0 & - & 0 & - \\
\hline & Mustela erminea & 3 & 0 & - & 0 & - & 0 & - \\
\hline & Mustela nivalis & 3 & 0 & - & $1(33.33)$ & $0.84-90.57$ & 0 & - \\
\hline & Martes foina & 4 & 0 & - & 0 & - & 0 & - \\
\hline & Martes martes & 1 & 0 & - & 0 & - & 0 & - \\
\hline Ursidae & Ursus arctos & 3 & 0 & - & 0 & - & 0 & - \\
\hline Total & & 432 & $7(1.62)$ & $0.79-3.31$ & $6(1.39)$ & $0.64-3.00$ & $1(0.23)$ & $0.25-44.50$ \\
\hline
\end{tabular}


Table 2 Dirofilaria immitis-positive animals

\begin{tabular}{|c|c|c|c|c|c|}
\hline \multicolumn{3}{|l|}{ Host species } & \multicolumn{2}{|c|}{ Necropsy (D. immitis) } & \multirow{2}{*}{$\begin{array}{l}\text { PCR } \\
\text { result }\end{array}$} \\
\hline & Sex & Age & Males & Females & \\
\hline \multirow[t]{10}{*}{ Canis aureus } & Female & Adult & 2 & 5 & Positive \\
\hline & Female & Adult & 2 & 3 & Positive \\
\hline & Male & Adult & 1 & 0 & Negative \\
\hline & Female & Juvenile & 1 & 1 & Negative \\
\hline & Female & Adult & 2 & 0 & Negative \\
\hline & Female & Adult & 1 & 2 & Positive \\
\hline & Male & Adult & 0 & 1 & Negative \\
\hline & Male & Adult & 1 & 1 & Positive \\
\hline & Female & Adult & 1 & 3 & Positive \\
\hline & Male & Juvenile & 1 & 2 & Negative \\
\hline Lutra lutra & Female & Juvenile & 1 & 2 & Negative \\
\hline Felis silvestris & Male & Adult & na & & Positive \\
\hline Vulpes vulpes & Female & Adult & na & & Positive \\
\hline
\end{tabular}

Abbreviation: na necropsy not performed, spleen sample collected directly in the field

otter, Lutra lutra (1/7; 16.67\%; 95\% CI: 0.42-64.12\%) and five golden jackals (5/66; 7.58\%, 95\% CI: $2.51-$ $16.80 \%$ ). However, all six spleen samples originating from those animals were negative for $D$. immitis DNA (Table 2). The presence of D. repens DNA was detected in splenic tissue of two golden jackals, two red foxes, one grey wolf, C. lupus, and one least weasel, Mustela nivalis (Table 1). Acanthocheilonema reconditum DNA was found only in one sample, originating from a red fox (Table 1). No co-infections were detected. The geographical distribution of the positive animals is shown in Fig. 1.

\section{Discussion}

The present study reports the presence of filarioid DNA in spleen samples collected from various species of wild carnivores throughout Romania. For Dirofilaria spp. the distribution pattern in wild carnivores in Romania is similar to that recorded in domestic dogs [33, 38-41]. Moreover, most positive animals originated from the south and southeast of the country, where the prevalence of infection in dogs is the highest, with values of up to $26 \%$ [33]. As wild carnivores are susceptible hosts, infections occur most often as an epi-phenomenon of dog infection, particularly in overlapping territories [42] However, infected microfilaremic carnivores may, in the presence of competent vector species, also act as reservoir hosts.

In Europe, D. immitis infections have been previously reported from several species of wild carnivores, but patency of infection was rarely evaluated (Table 3 ). Overall, in the present study, heartworm infections were detected in the case of one Eurasian otter, ten golden jackals, one wild cat and one red fox. However, DNA of D. immitis was not detected in all spleen samples, a fact indicating that the molecular positivity may be related to the presence of microfilariae, therefore, the occurrence of a patent infection. The lack of microfilaremia may be related to several factors, including unisexual infections, prepatency, or the hosts' immune response leading to the clearance of microfilariae [43]. The molecularly negative animals were either harbouring nematodes of the same sex, or were at juvenile age (under one year old) and had died during the winter. This would correspond to a relatively recent (prepatent) infection, considering that the prepatency period ranges between six and

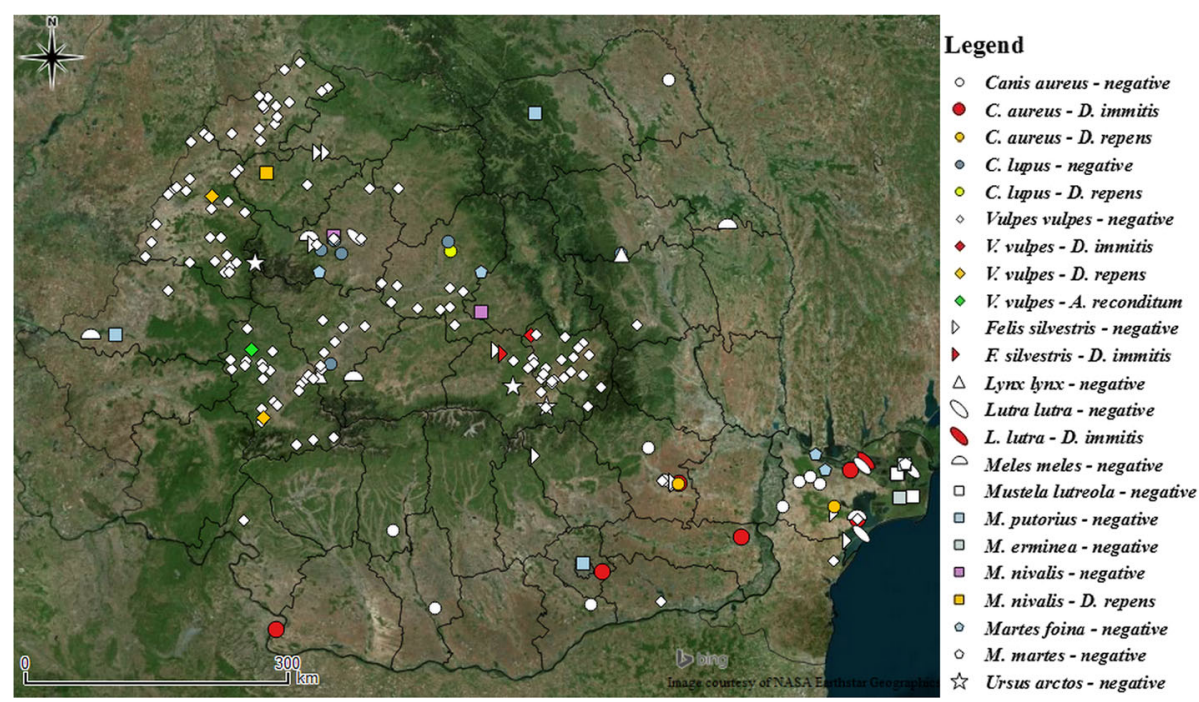

Fig. 1 Geographical origin of the samples examined in the country 
Table 3 An overview of diagnosed filarioid infections in wild carnivore species from Europe

\begin{tabular}{|c|c|c|c|c|c|c|c|c|}
\hline \multirow[t]{2}{*}{ Host species } & \multirow[t]{2}{*}{ Country } & \multicolumn{2}{|l|}{ D. immitis } & \multicolumn{2}{|l|}{ D. repens } & \multicolumn{2}{|l|}{ A. reconditum } & \multirow[t]{2}{*}{ Reference } \\
\hline & & $\begin{array}{l}\text { Prevalence in \% } \\
\text { (method) }\end{array}$ & Patency $^{a}$ & $\begin{array}{l}\text { Prevalence in \% } \\
\text { (method) }\end{array}$ & $\overline{\text { Patency }(\%)^{a}}$ & $\begin{array}{l}\text { Prevalence in \% } \\
\text { (method) }\end{array}$ & $\overline{\text { Patency }(\%)^{a}}$ & \\
\hline \multirow[t]{11}{*}{ Vulpes vulpes } & \multirow[t]{3}{*}{ Bulgaria } & 5.1 (necropsy) & not assessed & - & - & - & - & [9] \\
\hline & & 3.0 (necropsy) & not assessed & - & - & - & - & {$[12]$} \\
\hline & & 25.22 (necropsy) & not assessed & - & - & - & - & {$[16]$} \\
\hline & \multirow[t]{2}{*}{ Serbia } & 1.55 (necropsy) & not assessed & - & - & - & - & [14] \\
\hline & & - & - & 2.77 (necropsy) & not assessed & - & - & {$[21]$} \\
\hline & Hungary & 3.7 (necropsy) & 0 & - & - & - & - & {$[15]$} \\
\hline & \multirow[t]{2}{*}{ Italy } & 9.56 (necropsy) & 0.38 & 1.14 (smears) & 1.14 & 10.89 (smears) & 10.89 & [7] \\
\hline & & 6.06 (necropsy) & 1.51 & 0.75 (smears, PCR) & 0.75 & 9.09 (smears, PCR) & 9.09 & [13] \\
\hline & \multirow[t]{2}{*}{ Spain } & 12.7 (necropsy) & not assessed & - & - & - & - & [8] \\
\hline & & 0.4 (necropsy) & not assessed & - & - & - & - & [11 1] \\
\hline & Romania & 0.33 (PCR: spleen) & not assessed & 0.66 (PCR: spleen) & not assessed & 0.33 (PCR: spleen) & not assessed & Present study \\
\hline \multirow[t]{7}{*}{ Canis aureus } & \multirow[t]{3}{*}{ Bulgaria } & 4.4 (necropsy) & not assessed & - & - & - & - & [9] \\
\hline & & 8.9 (necropsy) & not assessed & - & - & - & - & {$[12]$} \\
\hline & & 37.54 (necropsy) & not assessed & - & - & - & - & [16] \\
\hline & Serbia & 7.32 (necropsy) & not assessed & - & - & - & - & [14] \\
\hline & Hungary & 7.4 (necropsy) & 0 & - & - & - & - & {$[15]$} \\
\hline & \multirow[t]{2}{*}{ Romania } & $\begin{array}{l}18.52 \text { (necropsy); } \\
9.26 \text { (PCR: blood) }\end{array}$ & not assessed & 1.85 (PCR: blood) & not assessed & 0 (PCR: blood) & not assessed & [17] \\
\hline & & $\begin{array}{l}15.15 \text { (necropsy); } \\
7.58 \text { (PCR: spleen) }\end{array}$ & not assessed & 3.03 (PCR: spleen) & not assessed & 0 (PCR: spleen) & not assessed & Present study \\
\hline \multirow[t]{7}{*}{ Canis lupus } & Bulgaria & 5.5 (necropsy) & not assessed & - & - & - & - & [9] \\
\hline & \multirow[t]{2}{*}{ Serbia } & 1.43 (necropsy) & not assessed & - & - & - & - & [14] \\
\hline & & - & - & 1.63 (necropsy) & not assessed & - & - & [21] \\
\hline & Macedonia & - & - & 10.0 (necropsy) & not assessed & - & - & [21] \\
\hline & Italy & 1 case (necropsy) & not assessed & - & - & - & - & [19] \\
\hline & Spain & 2.1 (necropsy) & not assessed & - & - & - & - & [10] \\
\hline & Romania & 0 (PCR: spleen) & not assessed & 7.14 (PCR: spleen) & not assessed & 0 (PCR: spleen) & not assessed & Present study \\
\hline \multirow[t]{2}{*}{ Felis silvestris } & Serbia & 7.69 (necropsy) & not assessed & - & - & - & - & [14] \\
\hline & Romania & 10 (PCR: spleen) & not assessed & 0 (PCR: spleen) & not assessed & 0 (PCR: spleen) & not assessed & Present study \\
\hline \multirow[t]{2}{*}{ Lutra lutra } & Portugal & 1 case (necropsy) & not assessed & - & - & - & - & [20] \\
\hline & Romania & $\begin{array}{l}16.67 \text { (necropsy); } \\
0 \text { (PCR: spleen) }\end{array}$ & not assessed & 0 (PCR: spleen) & not assessed & 0 (PCR: spleen) & not assessed & Present study \\
\hline Martes foina & Slovakia & 0 (PCR: spleen) & not assessed & 33.3 (PCR: spleen) & not assessed & 0 (PCR: spleen) & not assessed & {$[22]$} \\
\hline Mustela nivalis & Romania & 0 (PCR: spleen) & not assessed & 33.3 (PCR: spleen) & not assessed & 0 (PCR: spleen) & not assessed & Present study \\
\hline
\end{tabular}

${ }^{a}$ Assessed by microscopical visualization of microfilariae

nine months [44]. This represents the second record of D. immitis infection in two European species, otter and wild cat. Among mustelids, the reservoir status has been demonstrated experimentally for the domesticated form of the ferret (Mustela putorius furo) [45]. In the case of otters, the present study provides further evidence of the possibility of infection to occur. Apart from a single case, data regarding $D$. immitis infection in wild cats is currently absent, but their situation is probably similar to that of the domestic ones, which play a minimal epidemiological role, because they generally have a low worm burden and display low levels and a short duration of microfilaremia [46]. In red foxes, the recorded prevalence is considerably lower compared with those in neighbouring countries, such as Bulgaria or Hungary (Table 3). However, in most of these studies, the authors only reported the presence of adult nematodes and microfilaremia was not assessed. Similarly, in Italy the prevalence of adult heartworms in red foxes was of $9.56 \%(n=50)$, while microfilaremia was recorded in 
only $0.38 \%(n=2)$ of cases, indicating that red foxes may not be suitable reservoir hosts [7]. The low prevalence in our study may further support this theory.

So far, European records of D. repens in wildlife include only a handful of cases apart from red foxes (Table 3). To our knowledge, we provide the first evidence for a new host species, the least weasel, Mustela nivalis. Given that studies on $D$. repens infection in wild carnivores are mostly limited to singular cases, it is difficult to estimate their role in the epidemiology of this parasite. More comprehensive studies were performed on red foxes in Italy and revealed a relatively low prevalence of microfilaremia (Table 3). The prevalence recorded in foxes in the present study $(0.66 \%)$ has a similar low value. These data may indicate that red foxes are not efficient reservoir hosts.

Acanthocheilonema reconditum is a largely neglected and poorly known species of filarioid. Microfilariae develop and become infective in fleas or lice [47] and require proximity between infected and uninfected hosts [48]. So far, in Europe, among wild carnivores, this parasite has been documented only in red foxes from Italy, with relatively high prevalence values, suggesting their reservoir competence $[7,13]$. In the present study a single red fox $(0.33 \%)$ was positive. In Romania, in dogs, this species seems to be adapted to higher altitudes and to have a relatively large distribution area, despite the low prevalence [33]. However, neither data regarding the climatic requirements for development, nor full distribution maps are currently available for this species.

\section{Conclusion}

The present study provides molecular evidence for filarial infections in wild carnivore species present in Romania, suggesting a potential epidemiological role and demonstrates a new host species for $D$. repens.

\section{Acknowledgements}

We are indebted to Dan Traian lonescu, Daniel lordache, Sándor SikóBarabási, Botond J. Kiss and all others who provided samples and carcasses. We would like to express our gratitude to Miruna Oltean, Anamaria Balea, Zsuzsa Kalmár and any other colleagues who occasionally contributed to necropsy or DNA extraction. The work was done under the frame of the EurNegVec COST Action TD1303.

\section{Funding}

The present study was supported by the CNCS-UEFISCDI Grant Agency Romania, grant number TE 299/2015.

\section{Availability of data and materials}

The data supporting the conclusions are provided within the article.

\section{Authors' contributions}

AMI wrote the manuscript. DVE coordinated the collection of carcasses and/or field samples and managed their transportation. All authors participated in necropsy and sample collection. The molecular assays were performed by AMI, JA and IAM. ADS, CMG and ADM critically revised the manuscript for important intellectual content. All authors read and approved the final manuscript.
Ethics approval and consent to participate

Not applicable.

\section{Consent for publication}

Not applicable.

Competing interests

The authors declare that they have no competing interests.

\section{Publisher's Note}

Springer Nature remains neutral with regard to jurisdictional claims in published maps and institutional affiliations.

\section{Author details}

'Department of Parasitology and Parasitic Diseases, Faculty ofVeterinary Medicine, University of Agricultural Sciences and Veterinary Medicine Cluj-Napoca, Calea Mănăstur 3-5, 400372 Cluj-Napoca, Romania. ${ }^{2}$ Department of Engineering and Food and Tourism Management, Faculty of Food and Tourism, Transilvania University, Castelului Street, 500014 Braşov, Romania.

Received: 24 April 2017 Accepted: 4 July 2017

Published online: 13 July 2017

\section{References}

1. Anderson RC. Nematode parasites of vertebrates, their development and transmission. 2nd ed. Wallingford, Oxon, UK: CABI Publishing; 2000. p. 467-532.

2. Simón F, Siles-Lucas M, Morchón R, González-Miguel J, Mellado I, Carretón E, et al. Human and animal dirofilariasis: the emergence of a zoonotic mosaic. Clin Microbiol Rev. 2012;25:507-44.

3. Tarello W. Clinical aspects of dermatitis associated with Dirofilaria repens in pets: A review of 100 canine and 31 feline cases (1990-2010) and a report of a new clinic case imported from Italy to Dubai. J Parasitol Res. 2011; Article ID 578385.

4. Albanese F, Abramo F, Braglia C, Caporali C, Venco L, Vercelli A, et al. Nodular lesions due to infestation by Dirofilaria repens in dogs from Italy. Vet Dermatol. 2013;24:255-6.

5. Otranto D, Dantas-Torres F, Gianelli A, Latrofa MS, Papadopoulos E, Cardoso $L$, et al. Zoonotic Onchocerca lupi infection in dogs, Greece and Portugal, 2011-2012. Emerg Infect Dis. 2013;19:2000-3.

6. Otranto D, Dantas-Torres F, Brianti E, Traversa D, Petrić D, Genchi C, et al. Vector-borne helminths of dogs and humans in Europe. Parasit Vectors. 2013;6:16.

7. Marconcini A, Magi M, Macchioni G, Sassetti M. Filariosis in foxes in Italy. Vet Res Comm. 1996;20:316-9.

8. Gortázar C, Villafuente R, Lucientes J, Fernández de Luco D. Habitat related differences in helminth parasites of red foxes in the Ebro valley. Vet Parasitol. 1998:80:75-81.

9. Georgieva D, Kirkova Z, Ivanov A. A study on the incidence and diagnosis of dirofilariosis (heartworm disease) in carnivores. Bulg J Vet Med. 2001:4:231-6.

10. Segovia JM, Torres J, Miquel J, Llanezza L, Feliu C. Helminths in the wolf, Canis lupus, from north-western Spain. J Helminthol. 2001;75:183-92.

11. Mañas S, Ferrer D, Castellà J, López-Martín JM. Cardiopulmonary helminth parasites of red foxes (Vulpes vulpes) in Catalonia, northeastern Spain. Vet J. 2005:169:118-20.

12. Kirkova Z, Ivanov A, Georgieva D. Dirofilariosis in dogs and wild carnivores in Bulgaria. In: Genchi C, Rinaldi L, Cringoli G, editors. Mappe

Parassitologiche 8 - Dirofilaria immitis and D. repens in dog and cat and human infections. Naples: Rolando Editore; 2007. p. 204.

13. Magi M, Calderini P, Gabrielli S, Dell'Omodarme M, Macchioni F, Prati MC, et al. Vulpes vulpes: a possible wild reservoir for zoonotic filariae. Vector-borne Zoonot Dis. 2008;8:249-52.

14. Penezić A, Selaković S, Pavlović I, Ćirović D. First findings and prevalence of adult heartworms (Dirofilaria immitis) in wild carnivores from Serbia. Parasitol Res. 2014;113:3281-5.

15. Tolnai Z, Széll Z, Sproch Á, Szeredi L, Sréter T. Dirofilaria immitis: an emerging parasite in dogs, red foxes and golden jackals in Hungary. Vet Parasitol. 2014:203:339-42.

16. Panayotova-Pencheva MS, Mirchev RL, Trifinova AP. Dirofilaria immitis infection in carnivores from Bulgaria: 2012-2013 update. Bulg J Vet Med. 2016;19:153-62 
17. Ionică AM, Matei IA, D'Amico G, Daskalaki AA, Juránková J, lonescu DT, et al. Role of golden jackals (Canis aureus) as natural reservoirs of Dirofilaria spp. in Romania. Parasit Vectors. 2016;9:240.

18. Alho AM, Marcelino I, Colella V, Flanagan C, Silva N, Correia JJ, et al. Dirofilaria immitis in pinnipeds and a new host record. Parasit Vectors. 2017;10:142.

19. Pascucci I, Fico R, D'Angelo AR, Serini S, Cammà C. First notification in Italy of cardiopulmonary filariosis (heartworm disease) in a wolf (Canis lupus). Vet Ital. 2007:43:843-50.

20. Saraiva AL, Sousa S, Silva J, Andrade S, Botelho N, Canavarro I, et al. Dirofilaria immitis in a Eurasian otter (Lutra lutra). Proceedings of ESVP/ECVP. 2013; p. 88

21. Ćircović D, Penezić A, Pavlović I, Kulišić Z, Ćosić N, Burazerović J, et al. First records of Dirofilaria repens in wild canids from the region of Central Balkan. Acta Vet Hung. 2014;62:481-8.

22. Miterpáková M, Hurníková Z, Zalesny G, Chovancová B. Molecular evidence for the presence of Dirofilaria repens in beech marten (Martes foina) from Slovakia. Vet Parasitol. 2013;196:544-6.

23. Myers BJ, Kuntz RE, Wells WH. Helminth parasites of reptiles, birds, and mammals in Egypt VII. Check list of the nematodes collected from 19481955. Can J Zool. 1962:40:531-8.

24. Nelson GS, Heisch RB, Furlong M. Studies in filariasis in East Africa. II. Filarial infections in man, animals and mosquitoes on the Kenya coast. Trans R Soc Trop Med Hyg. 1962;56:202-17.

25. van Heerden J. Disease and mortality of captive wild dogs Lycaon pictus. S Afr J Wildl Res. 1986;16:7-11.

26. Sadighian A. Helminth parasites of stray dogs and jackals in Shahsavar area, Caspian region. Iran J Parasitol. 1969;55:372-4.

27. Meshgi B, Eslami A, Bahonar AR, Kharrazian-Moghadam M, GeramiSadeghian A. Prevalence of parasitic infections in the red fox (Vulpes vulpes) and golden jackal (Canis aureus) in Iran. Iran J Vet Res. 2009;10:387-91.

28. Kido N, Wada Y, Takahashi M, Kamegaya C, Omiya T, Yamamoto Y. Prevalence of Dirofilaria immitis infection in living raccoon dogs assessed by hematological examination. J Vet Med Sci. 2011;73:845-7.

29. Marks CA, Bloomfield TE. Canine heartworm (Dirofilaria immitis) detected in red foxes (Vulpes vulpes) in urban Melbourne. Vet Parasitol. 1998;78:147-54.

30. King AW, Bohning AM. The incidence of heartworm Dirofilaria immitis (Filarioidea), in the wild canids of northeast Arkansas. Southwest Nat. 1984;29:89-92.

31. Wixsom MJ, Green SP, Corwin RM, Fritzell EK. Dirofilaria immitis in coyotes and foxes in Missouri. J Wildl Dis. 1991;27:166-9.

32. Sacks BN, Woodward DL, Colwell AE. A long-term study of non-nativeheartworm transmission among coyotes in a Mediterranean ecosystem. Oikos. 2003;102:478-90.

33. Ionică AM, Matei IA, Mircean V, Dumitrache MO, D'Amico G, Győrke A, et al. Current surveys on the prevalence and distribution of Dirofilaria spp. and Acanthocheilonema reconditum infections in dogs in Romania. Parasitol Res. 2015;114:975-82

34. Ionică AM, D'Amico G, Mitková B, Kalmár Z, Annoscia G, Otranto D, et al. First report of Cercopithifilaria spp. in dogs from eastern Europe with an overview of their geographic distribution in Europe. Parasitol Res. 2014;113:2761-4.

35. Tudor P, Turcitu M, Mateescu C, Dantas-Torres F, Tudor N, Bărbuceanu F, et al. Zoonotic ocular onchocercosis caused by Onchocerca lupi in dogs in Romania. Parasitol Res. 2016;115:859-62.

36. Murariu D. Systematic list of the Romanian vertebrate fauna. Trav Mus Nat Hist Nat Grigore Antipa. 2010;53:377-411.

37. Latrofa MS, Weigl S, Dantas-Torres F, Annoscia G, Traversa D, Brianti E, et al. A multiplex PCR for the simultaneous detection of species of filarioids infesting dogs. Acta Trop. 2012;122:150-4.

38. Ciocan R, Darăbuș G, Jascó O, Fok É. Detection of Dirofilaria spp. in dogs by PCR. USAMV Bull. 2010;67:40-4.

39. Ciocan R, Mederle N, Jacsó O, Tánczos B, Fok É. Autochthonous cases of Dirofilaria in dogs from Timiş County (western part) Romania. Glob J Med Res. 2013:13:29-34.

40. Tudor P, Mateescu R, Tudor N. Dirofilaria infection in dogs from Târgovişte area, Romania. Curr Opin Biotechnol. 2013:24(Suppl. 1):S51-2.

41. Florea Cl, Olaru S, Dobrica A, Tudor P. Epidemiologically study about natural infestation with Dirofilaria in shelters located in the Southern part of Romania. In: Proceedings of the Fourth European Dirofilaria and Angiostrongylus Days (FEDAD). Budapest: ESDA; 2014. p. 43.

42. Otranto D, Cantacessi C, Dantas-Torres F, Brianti E, Pfeffer M, Genchi C, et al. The role of wild canids and felids in spreading parasites to dogs and cats in Europe. Part II: Helminths and arthropods. Vet Parasitol. 2015;213:24-37.
43. Rawlings CA, Dawe DL, McCall JW, Keith JC, Prestwood AK. Four types of occult Dirofilaria immitis infection in dogs. J Am Vet Med Assoc. 1982:180:1323-6.

44. McCall JW, Genchi C, Kramer LH, Guerrero J, Venco L. Heartworm disease in animals and humans. Adv Parasitol. 2008:66:193-285.

45. Campbell WC, Blair LS. Dirofilaria immitis: experimental infections in the ferret (Mustela putorius furo). J Parasitol. 1978;64:119-22.

46. Venco L. Heartworm (Dirofilaria immitis) disease in cats. In: Genchi C, Rinaldi L, Cringoli G, editors. Mappe Parassitologiche 8 - Dirofilaria immitis and D. repens in dog and cat and human infections. Naples: Rolando Editore; 2007. p. 128-32

47. Nelson GS. Dipetalonema reconditum (Grassi, 1889) from the dog with a note on its development in the flea, Ctenocephalides felis and the louse, Heterodoxus spiniger. J Helminthol. 1962;36:297-308.

48. Brianti E, Gaglio G, Napoli E, Gianetto S, Dantas-Torres F, Bain O, et al. New insights into the ecology and biology of Acanthocheilonema reconditum (Grassi, 1889) causing canine subcutaneous filariosis. Parasitology. 2012;139:530-6.

\section{Submit your next manuscript to BioMed Central and we will help you at every step:}

- We accept pre-submission inquiries

- Our selector tool helps you to find the most relevant journal

- We provide round the clock customer support

- Convenient online submission

- Thorough peer review

- Inclusion in PubMed and all major indexing services

- Maximum visibility for your research

Submit your manuscript at www.biomedcentral.com/submit
) Biomed Central 